\title{
PERAN KOMITMEN ORGANISASI SEBAGAI MEDIATOR PENGARUH ETIKA KERJA ISLAM TERHADAP SIKAP PADA PERUBAHAN
}

\author{
Irsad Andriyanto \\ STAIN KUDUS \\ E-mail: irsad.smg@gmail.com \\ Haerudin
UNIVERSITAS MUHAMMADIYAH SEMARANG \\ E-mail: abah_haerudin@yahoo.com
}

\begin{abstract}
The aim of this this study is to uncover the impact of Islamic Work Ethics on Attitude toward Change trough organizational commitment as mediating variable. CEO of BPRS (Bank Pembiayaan Rakyat Syariah) in Indonesia was asked to express their opinion about the statements in the questionaire. Structural Equation Modelling (SEM) was used to analyze the complect relationship in the model aided by Visual Partial Least Square (VPLS) software.The results indicated that there is no direct effect from Islamic work ethics on attitude toward change. The interested finding in this research showed that organizational commitement mediated Islamic work ethic in only one dimension, affective commitment. The implication of this research is that management need to develop the application of Islamic work ethic to increase organizational commitment, so that can bring up attitude of employees ready to face change even if only on affective dimension only.
\end{abstract}

Keywords: Islamic work ethic, organizational commitment, attitude toward change

\section{PENDAHULUAN}

Krisis 2008 ini terjadi disebabkan oleh negara-negara yang menjunjung tinggi faham kapitalisme. krisis ini menggerogoti dan menghancurkan perekonomian negara penganut kapitalisme tulen.Ketidakmampuan faham kapitalisme dalam menghadapi berbagai krisis, dikarenakan secara filosofis faham tersebut menimbulkan berbagai permasalahan dunia, seperti:Semakin banyaknya kemiskinan dan melebarnya jurang kaya miskin. Kerusakan lingkungan dan terjadinya berbagai bencana alam, Pemanasan global dan perubahan iklim yang tidak terduga, Hilangnya kasih sayang antar sesama, Semakin banyak perang dan konflik sosial, Muncul berbagai jenis penyakit aneh yang sukar disembuhkan baik penyakit manusia maupun penyakit sosial lainnya, dan Kebodohan, kekurangan gizi dan keterbelakangan sebagian besar penduduk.

Ekonomi Islam saat ini sudah saatnya unjuk gigi yang diharapkan mampu mencuri perhatian negara-negara Eropa dan Amerika. Ini adalah titik terang bagi ekonomi Islam untuk mulai dan menjadi jalan untuk menyelesaikan permasalahan krisis ekonomi global. Banyak negara membuka diri terhadap eksistensi bank-bank syariah, mereka melakukan perubahan mendasar dalam sistem ekonomi dan perbankan untuk mengakomodasi transaksi-transaksi syariah dan mengantisipasi aliran dana besar yang datang dari Timur Tengah akibat dari semakin naiknya harga minyak dunia. Berbagai program deregulasi dalam bidang keuangan diberlakukan dengan cepat. Sebagai contoh, Singapura hanya membutuhkan waktu 4 minggu untuk mempersiapkan peraturan tentang ekonomi syariah dan infrastruktur keuangannya. Pertumbuhan perbankan yang mengadopsi sistem syariah pun semakin membaik, dan semua pihak berlomba-lomba mencari peluang di dalamnya.

Tidak ketinggalan Indonesia pun terus berbenah mempersiapkan sarana dan prasarana sistem keuangan syariah. Praktek kehidupan keuangan dan perbankan syariah yang sekaligus merupakan suatu bentuk bisnis yang pada hakekatnya merupakan suatu kegiatan usaha individu atau secara kolektif yang terorganisir secara sistematis yang berupa penjualan barang dan jasa guna mendapatkan keuntungan dalam rangka memenuhi kebutuhan masyarakat, atau juga berbentuk suatu lembaga yang 
menghasilkan barang dan jasa yang dibutuhkan masyarakat semakin bergerak maju, meskipun demikian perangkat regulasi keuangan dan perbankan perlu penyempurnaan.

Perkembanganbank syariah terus maju dengan pesat sejak tahun 2005. Bahkan perkembangan menjadi jauh lebih pesat dari pada bank konvensional. Kendati demikian, tetap saja pangsa pasar perbankan syariah belum bisa menembus angka psikologis yang sudah ditetapkan sejak tujuh tahun yang lalu, hal ini dikarenakan bank-bank konvensional juga tumbuh seiring. Memang secara nominal perbankan syariah masih kecil, namun, kalau dilihat titik terangnya, perbankan syariah sangat menjanjikan, sekarang sudah ada 11 Bank Umum Syariah (BUS) dari 120 Bank (10\%), jumlah unit usaha syariah (UUS) sebanyak 24, pelayanan kebutuhan masyarakat semakin meluas dibanding 2012 yang tercermin dengan bertambahnya kantor cabang dari 452 kantor cabang menjadi 508, sementara kantor cabang pembantu (KCP) dan kantor kas meningkat sebanyak 440 kantor dibanding dengan periode yang sama (Oktober 2012). Secara keseluruhan jumlah kantor perbankan syariah yang beroperasi sampai dengan bulan Oktober 2012 dibanding tahun sebelumnya meningkat dari 1.692 kantor manjadi 2.188 kantor, sesuai dengan Undang Undang perbankan syariah pada tahun 2023 harus konversi menjadi Bank Umum Syariah, sehingga pada tahun 2023 akan terbentuk Bank Umum Syariah sebanyak 35 sehingga share nya 30\% akan melebihi Malaysia sekarang (23\%). Di samping itu jumlah Bank Pembiayaan Rakyat Syariah (BPRS) 155 buah. Total aset keseluruhan diperkirakan pada akhir tahun 2013 antara Rp. 255 trilyun sampai dengan Rp 296 trilyun.

Perkembangan Bank Syariah di Indonesia baik Bank Umum Syariah maupun Bank Pembiayaan Rakyat Syariah (BPRS) yang merupakan salah satu bentuk entitas organisasi, tidak akan terus berkembang secara otomatis hanya karena mempunyai label "syariah", tetapi juga perlu memperhatikan dan menanggapi perubahan-perubahan eksternal yang selalu berubah secara dinamis, kondisi ini menuntut organisasi untuk memiliki daya adaptasi terhadap lingkungan eksternal, oleh karena itu perubahan merupakan salah satu hal yang sangat penting pada era sekarang ini. Caplow menegaskan bahwa setiap organisasi harus memberikan apa yang diminta oleh lingkungannya dan permintaan tersebut bervariasi seiring dengan perubahan lingkungan. Atas dasar itu, manajemen di setiap organisasi dituntut untuk menanggapi perubahan tersebut dengan melakukan perubahanperubahan seperti memodifikasi struktur organisasi, goals, teknologi, serta penugasan, yang mana hasil tersebut sebagai alat dalam menghadapi lingkungan yang selalu berubah dan semakin kompleks.

Adanya perkembangan global yang semakin kompleks, menuntut disiplin organisasi untuk berperan nyata dalam semua proses sosial, ekonomi, politik, masyarakat dan lingkungannya. Hammer dan Champy menyebutkan bahwa ekonomi global berdampak terhadap $3 \mathrm{C}$, yaitu customer, competition, dan change, pelanggan menjadi penentu, pesaing makin banyak, dan perubahan menjadi konstan, tidak banyak orang yang suka akan perubahan, namun walau begitu perubahan tidak bisa dihindarkan, harus dihadapi, maka diperlukan satu manajemen perubahan agar proses dan dampak dari perubahan tersebut mengarah pada titik positif.

Hussey yang dikutip oleh Ayu Bianda Pramadani dan Fajrianthi mengatakan bahwa perubahan telah menjadi suatu kebutuhan primer bagi kehidupan organisasi, perubahan merupakan salah satu aspek yang paling kritis untuk menciptakan manajemen yang efektif. Dengan adanya perubahan yang berkelanjutan, maka manajemen harus memahami pengaruhnya terhadap lingkungan operasi dan sumber daya yang ada. Dalam sebuah organisasi, pihak yang bertanggung jawab untuk mengelola perubahan adalah agen perubahan, yang dapat berupa manajer atau bukan manajer seperti karyawan atau bahkan konsultan luar.

Setiap organisasi memerlukan sumber daya untuk mencapai usaha yang telah ditentukan, sumber daya manusia merupakan salah satu faktor penting yang terus menerus dibicarakan, oleh karena itu diperlukan usaha-usaha yang lebih bagi peningkatan dalam membina manusia sebagai tenaga kerja. Atas dasar itu, organisasi menjadi sangat tergantung pada manusia yang merupakan penentu penting atas kesuksesan atau kegagalan dari proses perubahan organisasi.

Demikian juga di Industri Perbankan Syariah termasuk didalamnya Bank Pembiayaan Rakyat Syariah (BPRS) membutuhkan kopentensi sumber daya manusia atau sumber daya Insani yang mempunyai peran sangat strategis dalam mendukung market inteligence baik dalam menganalisis pembiayaan maupun untuk memasarkan produk-produk syariah secara tepat. 
Faktor lain yang perlu diperhatikan adalah etika kerja Islam. Menurut Randall \& Cote etika kerja diprediksi mampu memberikan dorongan kepada karyawan untuk lebih terlibat dalam pekerjaannya, terlebih lagi pada organisasi-organisasi yang berlabelkan Islam.Penerapanetika kerja Islam menjadi suatu hal yang wajib dalam rangka membangun komitmen karyawannya secara alamiah.

Penerapanetika kerja Islam diharapkan akan meningkatkan kesiapan dari organisasi dalam mempersiapkan diri menghadapi lingkungan yang selalu berubah dengan penciptaan komitmen yang tinggi pada setiap anggotanya.

\section{Etika Kerja Islam}

Etika sering diletakan diluar sistem kehidupan, akibatnya banyak terjadi skandal baik di bidang politik, ekonomi, bisnis, budaya dan berbagai aspek lainnya, misalnya penyalahgunaan wewenang sehingga menjamurnya korupsi, kolusi dan nepotisme, banyak contoh yang bisa dilihat seperti adanya skandal perusahaan Enron di Amerika Serikat, belum lagi adanya bencana alam seperti banjir, longsor dan lain-lain, hal ini disebabkan kebijakan yang jauh dari etika, yang menganggap bahwa setiap urusan bisnis tidak dikenal adanya etika sebagai kerangka acuan, sehingga dalam pandangan mereka kegiatan bisnis adalah amoral, mereka menganggap bisnis adalah bisnis tidak ada hubungannya dengan etika.

Etika pada umumnya didefinisikan sebagai suatu usaha yang sistematis dengan menggunakan rasio untuk menafsirkan pengalaman moral individual dan sosial sehingga dapat menetapkan aturan untuk mengendalikan perilaku manusia serta nilai-nilai yang berbobot untuk dapat dijadikan sasaran dalam hidup. Pengertian ini persis sama dengan pengertian moralitas, dimana moralitas juga berasal dari kata latin mos, yang dalam bentuk jamaknya mores yang mengandung arti adat istiadat atau kebiasaan, Jadi melihat dari pengertian secara harfiah ini, etika dan moralitas sama sama mengandung arti sisten nilai tentang bagaimana manusia harus hidup dan telah diinstitusionalisasikan dalam sebuah adat kebiasaan yang kemudian terwujud dalam pola perilaku yang ajeg dan berulang dalam kurun waktu yang lama sebagaimana laiknya sebuah kebiasaan.

Secara sederhana etika adalah ilmu tentang apa yang dapat dilakukan atau ilmu tentang adat kebiasaan, disamping itu juga etika merupakan bidang ilmu yang bersifat normatif, karena berperan menentukan apa yang harus dilakukan atau tidak boleh dilakukan oleh seorang individu.

Etika yang berlaku di dunia barat merupakan etika rasional yaitu etika yang konsepsi etikanya didasarkan pada kemampuan manusia dan tidak menghubungkan perbuatan pada kehendak Tuhan, lebih jelasnya bahwa dasar dari etika rasional ini adalah logika. Terkadang manusia berfikir menurut logikanya, etika rasional ini bertindak berdasarkan sesuatu yang masuk akal (logis), tanpa menimbang hal baik atau buruk menurut Tuhan. Etika rasional ini menilai sesuatu berdasarkan rasionalitas manusia yang berakar pada pemikiran manusia tanpa diikat oleh moralitas yang berakar pada keyakinan atau agama, termasuk di bidang ekonomi, banyak yang menganggap bahwa ekonomi adalah nilai-nilai ekonomi yang tidak bisa dicampurbaurkan dengan nilai-nilai agama, nilai-nilai ketuhanan diletakan jauh diluar diri para pelaku ekonomi, mereka menganggap keduanya merupakan hal yang terpisah, paham ini masih terus berkembang dan dikenal dengan paham sekuler. Sehingga walaupun nampaknya sudah menggunakan etika tapi masih tetap muncul kecurangan-kecurangan bahkan skandal-skandal, kecurangan yang terjadi selalu bisa ditutupi atau dilepaskan dari jeratan hukum karena dapat diputarbalikan dengan kelihaian mantik atau bahasa pengacara populer.

Atas dasar itu perlu adanya etika yang berdasarkan keyakinan atau agama, secara umum agama (religion) diartikan sebagai persepsi dan keyakinan manusia terkait dengan eksistensinya, alam semesta, dan peran Tuhan terhadap alam semesta dan kehidupan manusia sehingga membawa kepada pola hubungan dan perilaku manusia dengan Tuhan, sesama manusia dan alam semesta.

Etika yang berdasarkan pada ajaran agama Islam, yang sering dikenal dengan etika Islam yang perhatiannya fokus terhadap Penciptanya, seperti diungkapkan oleh Beekum dalam Abdul Shukor bin Shamsudin dkk bahwa nilai etika Islam berbeda dengan etika barat atau sekuler.Etika Islam titik beratnya pada pola hubungan antara manusia dengan Penciptanya (Khaliq). Sebuah bisnis yang dilandasi dengan niat yang tulus, untuk mencari nafkah yang halal, untuk mengembangkan agama Allah merupakan ibadah tingkat tinggi.

Etika kerja mendapat perhatian dalam literatur perilaku organisasi yang mengandung beberapa nilai kerja seperti, prestasi, kepedulian, keadilan dan kejujuran. Sedang yang membedakan etika kerja 
berdasarkan syari'ah dengan etika lainnya adalah berkaitan dengan niat, cara memilih tujuannya, serta sumber penentuan nilai. Etika kerja Islam mengandung dua dimensi yaitu ukhrawi dan duniawi. Dalam dimensi ukhrawi, syari'ah menekankan pentingnya niat, yaitu semata-mata untuk mendapatkan keutamaan dari Tuhan. Sedangkan dimensi duniawi, syari'ah mengajarkan konsep ihsan untuk selalu menyempurnakan pekerjaan dan itqon yang berarti proses belajar yang sungguh-sungguh, akurat dan sempurna:

Hasil penelitian mengindikasikan bahwa etika kerja Islam secara langsung dan positif mempengaruhi sikap terhadap perubahan dan komitmen. Demikian pula hasil penelitian Fitria yang menyimpulkan bahwa affective commitment dan normative commitment berpengaruh positif terhadap sikap pada perubahan. Namun untuk variabel continuance commitment, diperoleh hasil yang negatif terhadap sikap pada perubahan. Randall dan Cote dengan berbagai pendekatannya menunjukkan bahwa keterlibatan kerja sangat dipengaruhi oleh etika kerja.

\section{Komitmen Organisasi}

Konsep komitmen organisasi telah didefinisikan dan diukur dengan berbagai cara yang berbeda. Porter, Mowday, dkk mendefinisikan komitmen organisasi sebagai kekuatan yang bersifat relatif dari individu dalam mengidentifikasikan keterlibatan dirinya ke dalam bagian organisasi. Sedangkan Richard M. Steers mendefinisikan komitmen organisasi sebagai rasa identifikasi (kepercayaan terhadap nilai-nilai organisasi), keterlibatan (kesediaan untuk berusaha sebaik mungkin demi kepentingan organisasi) dan loyalitas (keinginan untuk tetap menjadi anggota organisasi yang bersangkutan) yang dinyatakan oleh sesorang pegawai terhadap organisasinya.

Reicher mengatakan bahwa komitmen terhadap organisasi merupakan penerimaan tujuan dan nilai-nilai organisasi, dimana derajat dari komitmen didefinisikan sebagai kesediaan untuk mendedikasikan diri pada nilai dan tujuan organisasi. Sedangkan Porter dan Smith mendefinisikan komitmen organisasi sebagai sifat hubungan antara pekerja dan organisasi yang dapat dilihat dari keinginan kuat untuk tetap menjadi anggota organisasi tersebut, kesediaan untuk menjadi sebaik mungkin demi kepentingan organisasi tersebut dan kepercayaan dan penerimaan yang kuat terhadap nilai-nilai dan tujuan organisasi.

Menurut Aranya dkk komitmen organisasi didefinisikan sebagai berikut:

1. Sebuah kepercayaan dan penerimaan terhadap tujuan-tujuan dan nilai-nilai dari organisasi dan atau profesi.

2. Sebuah kemauan untuk menggunakan usaha yang sungguh-sungguh guna kepentingan organisasi dan atau profesi.

3. Sebuah keinginan untuk memelihara keanggotaan dalam organisasi dan atau profesi.

Secara singkat pada intinya beberapa definisi komitmen organisasi dari beberapa ahli diatas mempunyai penekanan yang hampir sama yaitu proses pada individu (pegawai) dalam mengidentifikasikan dirinya dengan nilai-nilai, aturan-aturan, dan tujuan organisasi. Disamping itu, komitmen organisasi mengandung pengertian sebagai sesuatu hal yang lebih dari sekedar kesetiaan yang pasif terhadap organisasi, dengan kata lain komitmen organisasi menyiratkan hubungan pegawai dengan perusahaan atau organisasi secara aktif. Karena pegawai yang menunjukkan komitmen tinggi memiliki keinginan untuk memberikan tenaga dan tanggung jawab yang lebih dalam menyokong kesejahteraan dan keberhasilan organisasi tempat bekerja.

Meningkatkan atau paling tidak mempertahankan komitmen merupakan solusi untuk mengatasi masalah turnover dan absenteeisme, sebab hadirnya komitmen dalam diri karyawan akan memberikan keuntungan bagi organisasi atau perusahaan, seperti mendapat dukungan optimal dari para karyawan dan mengurangi biaya dalam pemeliharaan sumber daya manusia. Hal ini akan berdampak pada pengurangan kasus-kasus kemangkiran dan berkurangnya turnover.

Komitmen karyawan dapat dikembangkan dengan cara organisasi merekrut dan menyeleseksi calon karyawan yang memiliki kecocokan dengan nilai organisasi. Jadi seseorang yang memiliki komitmen tinggi akan memiliki identifikasi terhadap organisasi dapat dilihat:

1. Keinginan kuat untuk tetap menjadi anggota organisasi tersebut,

2. Kesediaan untuk berusaha sebaik mungkin demi kepentingan organisasi tersebut

3. Kepercayaan akan ada penerimaan yang kuat terhadap nilai-nilai dan tujuan organisasi. 
Jenis penelitian komitmen organisasi yang akan digunakan dalam penelitian ini adalah jenis komitmen organisasi menurut Allen dan Meyer (affective commitment, normative commitment dan continuance commitmnet). Komponen affektif berkaitan dengan emosional, identifikasi dan keterlibatan pegawai di dalam suatu organisasi. Komponen normatif merupakan perasaan-perasaan pegawai tentang kewajiban yang harus ia berikan kepada organisasi. Komponen continuance berarti komponen berdasarkan persepsi pegawai tentang kerugian yang akan dihadapinya jika ia meninggalkan organisasi.

\section{Sikap terhadap Perubahan Organisasi}

Kesiapan untuk berubah didefinisikan sebagai sikap komprehensif yang secara simultan dipengaruhi oleh isi, proses, konteks, dari individu yang terlibat dalam suatu perubahan, merefleksikan sejauh mana kecenderungan individu untuk menyetujui, menerima, dan mengadopsi rencana spesifik yang bertujuan menghadapi perubahan yang sewaktu-waktu utuk mengubah keadaan saat ini.

Untuk mencapai kerberhasilan dalam melakukan perubahan, organisasi senantiasa harus tetap berada dalam kesiapan berubah, namun kesiapan untuk berubah juga harus didukung oleh semua elemen yang ada dalam organisasi tersebut, mempersiapkan diri dengan baik dan selalu siap untuk berubah.Para manajer sering kali terperangkap dalam pemikiran bahwa hanya ada satu resep yang benar, memproyeksikan masa lalu untuk masa yang akan depan, percaya bahwa ancaman lamayang membawa keberhasilan masih relevan, dan menganggap industrinya stabil.

Umumnya organisasi masa kini menghadapi suatu dinamika dan lingkungan yang sedang berubah secara terus menerus, dimana dalam hal ini menghendaki organisasi untuk dapat menyesuaikan diri. Dengan demikian untuk mendapat kemajuan yang sesungguhnya hanya dapat dicapai dengan membuat orang bertindak secara berbeda atau melakukan perubahan dalam bisnisnya.Olehkarenanyaterkadang diperlukan investasi yang besar dan perubahan model mental para manajernya.

Pola pikir model mental dari manajer yang cenderung mempertahankan status quo akan mempengaruhi terjadinya perubahan, yang oleh William Davishal dikatakan sebagai sebuah ironi dimana halangan terbesar untuk melakukan perubahan justru datang dari individu yang mempunyai peran besar. Walaupun demikian bukannya mereka tidak suka pada saran dan tindakan yang lebih baik, tetapi ada yang berkepentingan untuk mempertahankan status quo.

Robbins mengemukakan bahwa yang bertanggung jawab untuk mengelola kegiatan perubahan adalah agen perubahan, dimana agen perubahan tersebut bisa manajer atau bukan manajer, karyawan atau konsultan luar. Sedangkan yang dapat diubah oleh agen perubahan pada hakekatnya dapat dikelompokkan dalam empat kategori:

1. Struktur, mengubah struktur mencakup pembuatan perubahan dalam hubungan wewenang, mekanisme koordinasi dan rancang ulang pekerjaan.

2. Teknologi, Mengubah teknologi meliputi modifikasi dalam cara kerja yang di proses dan dalam metode serta peralatan yang digunakan.

3. Setting fisik, Mengubah setting fisik meliputi pengubahan ruang dan pengaturan tata letak dalam tempat kerja.

4. Orang. Mengubah orang mengacu pada perubahan dalam sikap, ketrampilan, pengharapan, persepsi dan atau perilaku karyawan.

Menurut Siegel ada tiga komponen sikap terhadap perubahan:

1. Komponen Cognitive

Komponen Cognitive berasal dari ide, persepsi dan kepercayaan yang dimiliki seseorang mengenai obyek yang disikapi.

2. Komponen Affective

Komponen affective yaitu tentang perasaan yang dimiliki seseorang terhadap sesuatu.

3. Komponen Behavioral

Komponen behavioral yaitu bagaimana seseorang bereaksi terhadap sesuatu.

Kekuatan lingkungan (kondisi ekonomi, karakteristik angkatan kerja, kualitas sosial) menyebabkan perubahan organisasi berubah-ubah dari waktu ke waktu dan dari satu bisnis ke bisnis lainnya, namun proses perubahan itu sendiri bersifat konstan. Terdapat tiga contoh perubahan 
organisasi yang memiliki implikasi utama terhadap pengelolaan sumber daya manusia dan sangat mungkin tetap berlangsung udalam abad 21:

1. Perubahan yang terus berlangsung ke arah strategi yang berfokus pada konsumen dan kualitas menyeluruh,

2. Restrukturisasi organisasi dan terus berlangsungnya upaya perampingan perusahaan dan pemutusan hubungan kerja dan

3. Inisiatif untuk berespon terhadap tuntutan angkatan kerja yang semakin beragam.

\section{Hipotesis Penelitian}

Hipotesis 1: $\quad$ Penerapan Etika Kerja Islam berpengaruh positif terhadap dimensi kognitif sikap pada perubahan

Hipotesis 2: $\quad$ Penerapan Etika Kerja Islam berpengaruh positif terhadap dimensi afektif sikap pada perubahan

Hipotesis 3: $\quad$ Penerapan Etika Kerja Islam berpengaruh positif terhadap dimensi perilaku sikap pada perubahan

Hipotesis 4: $\quad$ Etika Kerja Islam berpengaruh positif terhadap Komitmen Organisasi

Hipotesis 5: $\quad$ Komitmen organisasi berpengaruh positif terhadap dimensi kognitif sikap karyawan pada perubahan.

Hipotesis 6. Komitmen organisasi berpengaruh positif terhadap dimensi afektif sikap karyawan pada perubahan.

Hipotesis 7. Komitmen organisasi berpengaruh positif terhadap dimensi perilaku dari sikap karyawan pada perubahan

Gambar 2

Model Pengaruh Etika Kerja Islamterhadap Sikap pada perubahan Organisasi dengan Komitmen Organisasi sebagai mediator

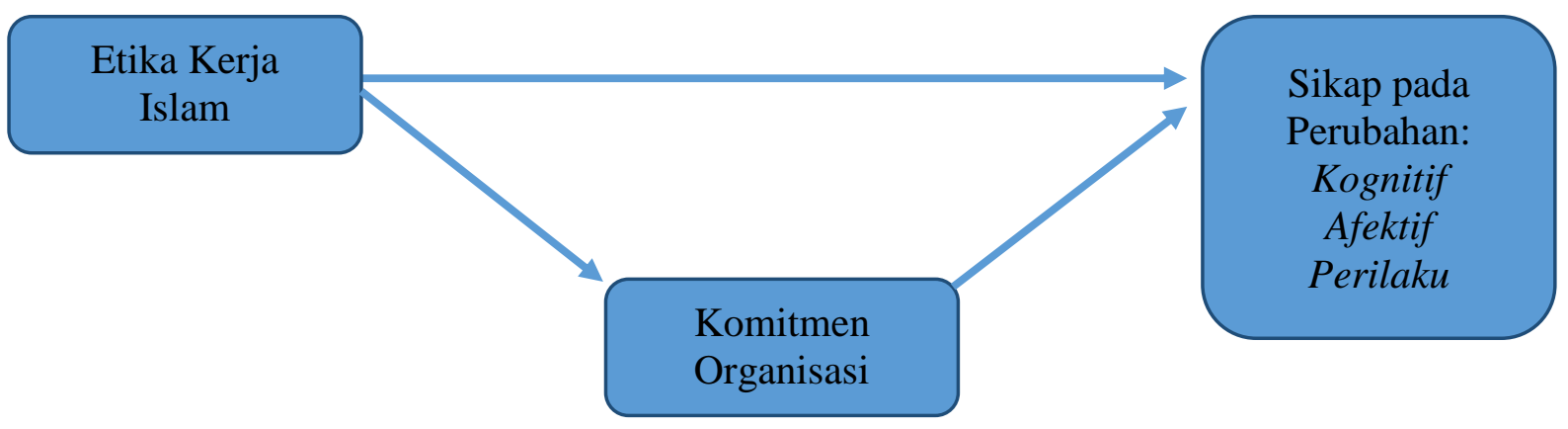

\section{METODE PENELITIAN}

\section{A. Populasi.}

Dalam penelitian ini untuk mendapatkan data tentang variabel penelitian tidak menggunakan metode sampel tetapi menggunakan sensus sehingga semua anggota populasi dijadikan responden, hal ini dikarenakan data yang tersedia hanya 155 unit BPRS (Bank pembiayaan Rakyat Syariah).Adapunobjek yang menjadi populasi dalam penelitian ini adalah manajer atau direktur BPRS (Bank pembiayaan Rakyat Syariah) seluruh Indonesia.

\section{B. Definisi Operasional dan Pengukuran Variabel \\ 1. Etika Kerja Islam}

Etika kerja yang dimaksud dalam penelitian ini adalah etika kerja dalam perspektif Islam yang diartikan sebagai pancaran dari Akidah yang bersumber dari sistem keimanan Islam yakni, sebagai sikap hidup yang mendasar berkenaan dengan kerja yang bersumber dari Al-quran dan Hadist, yang mendedikasikan kerja sebagai suatu kebajikan. 
Variabel Etika kerja Islam diukur dengan menggunakan versi instrumen Ali Abas yang terdiri dari 17 item. Instrumen ini menggunakan skala likert 5 poin dengan skor 1: sangat tidak setuju, 2: tidak setuju, 3: netral, 4: setuju dan 5 sangat setuju.

\section{Komitmen Organisasi}

Komitmen organisasi sebagai sifat hubungan antara pekerja dan organisasi yang dapat dilihat dari keinginan kuat untuk tetap menjadi anggota organisasi tersebut, kesediaan untuk menjadi sebaik mungkin demi kepentingan organisasi tersebut dan kepercayaan dan penerimaan yang kuat terhadap nilai - nilai dan tujuan organisasi.

Aranya et al.. mengatakan bahwa Komitmen organisasi didefinisikan sebagai : (1) suatu kepercayaan dan penerimaan pada tujuan dan nilai organisasi, (2) suatu keinginan menggunakan usaha yang sungguh-sungguh untuk kemajuan organisasi, dan (3) suatu dorongan untuk mempertahankan keanggotaan dalam organisasi.

Jenis penelitian komitmen organisasi yang akan digunakan dalam penelitian ini adalah jenis komitmen organisasi menurut Allen dan Meyer, yang terdiridari 10 item pertanyaan. Instrumen ini menggunakan skala likert 5 poin dengan skor 1: sangat tidak setuju, 2: tidak setuju, 3: netral, 4: setuju dan 5 sangat setuju.

\section{Sikap pada Perubahan Organisasi}

Sikap terhadap organisasi dalam penelitian ini menunjukkan derajat seberapa besar dukungan individu terhadap perubahan yang terjadi dalam organisasi. Sikap terhadap perubahan organisasi tersebut dibedakan menjadi tiga dimensi yaitu: cognitive (ide untuk berubah), affective (menginginkan) dan behavioral tendency (kecenderungan untuk berperilaku). Sikap terhadap perubahan organisasi diukur dengan menggunakan instrumen Dunham et al. dalam Yousef yang terdiri dari 18 item yang dibedakan dalam tiga sub skala yaitu: cognitive, affective, dan behavioral tendency, masing-masing sub skala terdiri dari 6 item. Instrumen ini menggunakan skala likert 5 point dengan skor 1: sangat tidak setuju, 2: tidak setuju, 3: netral, 4: setuju dan 5 sangat setuju.

\section{Teknik Analisis Data}

Untuk menguji hipotesis, digunakan analisis multivariate dengan model persamaan struktural (Structural Equation Model/SEM). SEM merupakan kombinasi metodologi dua disiplin ilmu, yaitu model analisis faktor konfirmatori (confirmatory factor analysis model) yang diambil dari psychometric dan model persamaan struktuktural (structure equation model) yang diambil dari econometrics. Model ini dipilih karena memiliki kemampuan tidak hanya menguji hubungan kausal antara variabel dependen dengan variabel independen (model struktural), tetapi juga validitas dan reliabilitas dari variabel laten (model pengukuran). Penelitian ini menggunakan metode alternatif dengan partial least square (PLS).

\section{Hasil Penelitian}

Setelah melakukan pengujian atas model pengukuran (outer model), selanjutnya dilakukan pengujian terhadap model struktural. Pengujian ini dimaksudkan untuk mengevaluasi hubungan antar konstruk yang telah diajukan pada hipotesis penelitian ini. Dengan menggunakan VPLS 2.0 M3 , dihasilkan dua jenis informasi yang menunjukkan berapa baiknya model struktural yang diprediksikan dan hubungan yang telah dihipotesiskan. Informasi pertama didapat dengan melihat nilai $R$ square yang merupakan uji goodness-fit model untuk menjelaskan persentase variasi konstruk terhadap keseluruhan model. Dengan menggunakan output VPLS 2.0 M3 dan metode bootstrapping 500 sampel, seperti yang ditampilkan pada Tabel 1, dapat dilihat nilai $R$ square setiap variabel endogen.

Hasil penerimaan dan penolakan terhadap hipotesis yang diajukan dalam penelitian ini selanjutnya disajikan dalam Tabel berikut:

Tabel Ringkasan Pengujian Hipotesis Penelitian

\begin{tabular}{|ll|l|}
\hline \multicolumn{1}{|c|}{ Hipotesis } & \multicolumn{1}{|c|}{ Hasil } \\
\hline 1: & $\begin{array}{l}\text { Penerapan Etika Kerja Islam berpengaruh positif terhadap dimensi kognitif Sikap } \\
\text { Pada Perubahan }\end{array}$ & Ditolak \\
\hline 2: & $\begin{array}{l}\text { Penerapan Etika Kerja Islam berpengaruh positif terhadap dimensi affektif Sikap Pada } \\
\text { Perubahan }\end{array}$ & Ditolak \\
\hline 3. & $\begin{array}{l}\text { Penerapan Etika Kerja Islam berpengaruh positif terhadap dimensi behavioral Sikap } \\
\text { Pada Perubahan }\end{array}$ & Ditolak \\
\hline
\end{tabular}




\begin{tabular}{|lll|l|}
\hline \multicolumn{1}{|c|}{ Hipotesis } & Hasil \\
\hline 4: & Etika Kerja Islam berpengaruh terhadap Komitmen Organisasi & Diterima \\
\hline 5: & $\begin{array}{l}\text { Komitmen Organisasi berpengaruh positif terhadap dimensi kognitif Sikap pada } \\
\text { Perubahan }\end{array}$ & Ditolak \\
\hline 6: & $\begin{array}{l}\text { Komitmen Organisasi berpengaruh positif terhadap dimensi afektif Sikap pada } \\
\text { Perubahan }\end{array}$ & Diterima \\
\hline 7: & $\begin{array}{l}\text { Komitmen Organisasi berpengaruh positif terhadap dimensi behavioral Sikap pada } \\
\text { Perubahan }\end{array}$ & Ditolak \\
\hline
\end{tabular}

Sumber: Data diolah, 2016

\section{PEMBAHASAN}

a. Pembahasan hipotesis 1, 2 dan 3:

Hipotesis 1. (Penerapan Etika Kerja Islam berpengaruh positif terhadap dimensi kognitif Sikap Pada Perubahan).

Hipotesis 2. (Penerapan Etika Kerja Islam berpengaruh positif terhadap dimensi Afektif Sikap Pada Perubahan).

Hipotesis 3. (Penerapan Etika Kerja Islam berpengaruh positif terhadap dimensi perilaku dari Sikap Pada Perubahan).

Hipotesis 1, 2, dan 3 menyatakan bahwa Etika Kerja Islam berpengaruh positif terhadap Sikap pada Perubahan baik dimensi kognitif, afektif dan behavioral. Penelitian ini memberikan hasil empiris yang tidak mendukung hipotesis-hipotesis tersebut. Hal ini berarti bahwa dari hasil penelitian ini etika kerja Islam tidak signifikan berpengaruh secara langsung pada sikap terhadap perubahan baik dimensi kognitif, afektif maupun bihavioral.

Hasil penelitian ini berbeda dengan hasil penelitian Yousef yang menyatakan bahwa etika kerja Islam mempengaruhi secara langsung dan positif pada berbagai dimensi sikap terhadap perubahan organisasional dan komitmen organisasional, demikian juga penelitian yang dilakukan oleh Cahyono (2001), Fitria (2003) dan Arifudin dkk (2002),. Walaupun demikian, penolakan hipotesis ini sejalan dengan penelitian yang dilakukan oleh Indiarti Januarti dan Ashari Bunyanudin, yang mengatakan bahwa etika kerja tidak berpengaruhi secara langsung terhadap sikap terhadap perubahan, dengan memasukkan variabel keterlibatan kerja maka ada hubungan yang kuat antara hubungan etika kerja Islam dengan sikap terhadap perubahan.

Untuk memperdalam hasil penelitian, peneliti juga melakukan wawancara dengan direksi BPRS Jawa Tengah. Dari hasil wawancara dapat diketahui bahwa pelaksanaan etika kerja Islam sudah baik. Mereka kerja keras untuk menyelesaikan tugas-tugasnya, telah melaksanakan usaha-usaha maksimal dalam memenuhi target-target yang telah dibebankan oleh pemegang saham, bertindak jujur, disiplin dan dalam melaksanakan pekerjaannya selalu berpedoman pada syariah Islam, terutama dalam oprasional perbankan syariah.

Semangat untuk menyesuaikan dengan perubahan-perubahan di lingkungan eksternal sudah nampak pada penggunaan teknologi informasi sudah mereka terapkan. Alasan yang melandasinya adalah bukan hanya sekedar mengikuti instruksi Bank Indonesia tetapi juga karena kesadaran bahwa penggunaan teknologi informasi merupakan suatu kebutuhan untuk bisa bersaing dengan melakukan pelayanan cepat dan akurat.

\section{b. Pembahasan Hipotesis 4 (Etika kerjaIslam berpengaruh positif terhadap Komitmen Organisasi)}

Dari hasil analisa menunjukkan bahwa etika kerja Islam mempengaruhi secara langsung dan poitif terhadap komitmen organisasi. Hasil penelitian ini dengan hasil penelitian Oliver, Saks dkk., Putti dkk., Morrow, Mc. Elroy, Mochammad Maksum yang menunjukkan bahwa terdapat hubungan yang signifikan antara etika kerja dengan komitmen organisasi. Hasil ini juga sejalan dengan penelitian Rahman dan Mohamed yang dilakukan sebelumnya di Malaysia.

Direksi BPRS di Jawa Tengah khususnya mengetahui bahwa norma Islami mereka berkorespondensi dengan nilai-nilai tempatnya bekerja maka komitmen organisasinya terutama komitment afektif dan normatif akan meningkat. Komitment afektif berkaitan dengan keterikatan emosional, identifikasi, dan keterlibatan dalam organisasi. Sedangkan komitmen normative 
berhubungan dengan perasaan untuk wajib berada dalam organisasi karena itu adalah tindakan yang benar. Etika kerja Islam memberikan panduan nilai untuk membangun keeratan emosi dan perasaan wajib berada di dalam organisasi karena ada persamaan nilai diri dan norma universalitas.

Etika kerja Islam khususnya dalam pengaruhnya terhadap komitmen organisasi ternyata cenderung dipengaruhi asumsi bahwa bekerja merupakan aktualisasi perkembangan pribadi dan hubungan sosial. Komitmen organisasi menunjukan bahwa terdapat perasaan ikut memiliki, tetap bekerja di organisasi atau lembaga merupakan kebutuhan sekaligus juga sebagai sebuah keinginan, cenderung dipengaruhi oleh loyalitas terhadap organisasi atau lembaga. Oleh karena itu, direksi dengan nilai etika kerja Islam yang kuat akan memiliki komitmen organisasi yang tinggi pula.

Bank syariah sebagai institusi perbankan yang belandaskan syariah Islam, memiliki perbedaan dengan bank konvensional dalam hal iklim etisnya. Iklim etis adalah perasaan para pekerja tentang perilaku yang benar atau salah, baik atau buruk dalam bekerja, atau tentang bagaimana bersikap dan berperilaku dengan cara yang seharusnya. Iklim etis tercipta, jika dalam suatu perusahaan terdapat kumpulan-kumpulan pengertian tentang perilaku apa yang dianggap benar dan tersedia yang memungkinkan permasalahan menganai etika dapat diatas. Nilai-nilai Islam akan memainkan peran penting dalam iklim etis yang ada dan dianut dalam bank syariah, hal ini akan sangat membantu dalam pelaksanaan etika kerja Islam yang sekaligus mempengaruhi komitmen organisasi direksi.

Direksi BPR Syariah di Jawa Tengah dalam menjalankan tugasnya mempunyai komitmen yang sangat tinggi, hal ini sesuai dengan profil responden berdasarkan masa kerja dimana masa kerja 3- 5 tahun 44\%, diatas 5-10 tahun 36\%, diatas 10 tahun 10\%, itupun rata-rata direksi BPRS di Jawa Tengah berasal dari karyawan BPRS yang bersangkutan. Komitmren direksi yang cukup tinggi tersebut dikarenakan mereka bekerja bukan hanya mencari uang, justru lebih diakarenakan kesesuaian antara perlaksanaaan sistem perbankan syariah dengan keyakinan mereka bahwa bunga bank adalah riba yang secara jelas telah diharamkan. Mereka juga berkeyakinan bahwa BPRS yang mereka pimpin akan berkembang dengan baik jika memperhatikan dan menyesuaikan dengan perkembangan perubahan lingkungannya, sehingga mereka selalu menyesuaikan dengan perubahan-perubahan lingkungan, misalnya dengan menggunakan teknologi informasi dalam operasional BPRS yang dipimpinannya.

c. Pembahasan:

Hipotesis 5 (komitmen organisasi berpengaruh positif terhadap sikap karyawan pada perubahan dimensi kognitif)

Hipotesis 6 (komitmen organisasi berpengaruh positif terhadap sikap karyawan pada perubahan dimensi afektif)

Hipotesis 7 (komitmen organisasi berpengaruh positif terhadap sikap karyawan pada perubahan dimensi perilaku)

Hasil penelitian ini menunjukan bahwa komitmen organisasi berpengaruh positif terhadap sikap karyawan pada perubahan hanya pada dimensi afektif saja, sedangkan pada dimensi kognitif dan behavioral tidak berpengaruh. Penelitian ini sejalan dengan temuan Iverson yang konsisten dengan model Guest melaporkan bahwa komitmen organisasi sebagai mediator pengaruh kausal total dari positive affectivity, keamanan kerja (job security), kepuasan kerja (job satisfaction), motivasi kerja (job motivation), dan kesempatan lingkungan (environmental opportunity) terhadap perubahan organisasional. Hasil ini juga sesuai dengan penelitian dari Madsen dkk. dan Eby dkk. yang menunjukkan bahwa komitmen organisasi memiliki hubungan yang kuat dengan kesiapan individu untuk berubah. Ayu Bianda Pramadani dan Fajrianthi (2012) menemukan bahwa terdapat hubungan antara komitmen organisasi dengan dengan kesiapan berubah, dengan demikian komitmen organisasi memediasi antara etika kerja Islam dengan sikap pada perubahan pada dimensi afektif.

Armenakis dkk yang dikutip oleh I Putu Esa Widaharthan menjelaskan bahwa komitmen merupakan salah satu faktor terpenting yang melandasi keterlibatan karyawan dalam mendukung inisiatif perubahan. Conner dan petterson menyatakan bahwa faktor yang mengakibatkan usaha perubahan mengalami kegagalan adalah disebabkan adanya kesenjangan antara komitmen individual dan organisasi.

Herscovitch dan Meyer menyebutkan bahwa komitmen pada perubahan merupakan mind set yang mengikat seseorang individual pada rangkaian tindakan yang mempertimbangkan perlunya mensukseskan implementasi terhadap inisiatif perubahan, terdapat tiga mind set yang mengikat seorang individual pada serangkaian tindakan tersebut dapat merefleksikan: 
1. Keinginan untuk memberikan dukungan terhadap perubahan yang dilandasi pada kepercayaan bahwa perubahan memiliki manfaat (komitmen afektif terhadap perubahan).

2. Suatu pengakuan bahwa terdapat biaya-biaya yang "dikaitkan dengan" kemungkinan perubahan mengalami kegagalan (komitmen kontinuan)

3. A sense of obligation dalam memberikan dukungan terhadap perubahan.

BPRS tidak bisa dipisahkan dari lingkungan, baik mikro maupun makro.Dengan demikian tujuan organisasi baru bisa dicapai jika mempunyai kemauan dan kemampuan untuk dapat menyesuaikan dengan perubahan lingkungan, sehinga dengan demikian SDM nya terutama direkturnya juga harus mempunyai kemauan untuk beradaptasi dengan perubahan lingkungan.

BPRS tidak akan sanggup bertahan tanpa melakukan perubahan. BPRS harus mempunyai tatakelola yang lebih efektif dan efisien sebagai sebuah tantangan yang akan terus mengalami perkembangan. BPRS sebagai sebuah entitas sosial yang terdiri dari berbagai macam individu harus dapat mengelola perubahan dengan baik, untuk itu dukungan komitmen direktur sangat penting, sehingga dapat mempertahankan kelangsungan hidup dan pengembangan perusahaan.

Perubahan merupakan salah satu proses yang dapat membawa perusahaan untuk mencapai tujuannya, sehingga direksi yang memiliki komitmen terhadap perusahaan akan berpartisipasi secara aktif dalam menghadapi perubahan agar perusahaan dapat mencapai tujuannya. Selain itu, direksi dengan komitmen yang tinggi terhadap perusahaan juga memiliki kelekatan emosi terhadap perusahaan, sehingga ia akan cenderung memiliki motivasi untuk memberikan kontribusi yang berarti dalam perubahan.

Temuan-temuan penelitian ini dapat diuraikan secara garis besar sebagai berikut:

1. Etika kerja Islam tidak berpengaruh secara langsung terhadap sikap pada perubahan, hasil penelitan ini berbeda dengan penelitian Darwish A Yousef (2000), perbedaan ini dimungkinkan karena budaya yang berbeda, dimana penelitianYousef dilakukan di Emirat Arab, walaupun demikian sejalan dengan hasil penelitian Indiarti Januarti dan Ashari Bunyanudin (2006).

2. Komitmen organisasi berpengaruh terhadap sikap pada peruabahan tetapi hanya pada dimensi afektif, sejalan dengan hasil penelitian Maria valoka dan Ioanis Nikolaou (2005), Madsen Susan dkk (2005), Alfonsus B Susanto (2008).

3. Dengan memperhatikan hasil penelitian ini maka etika kerja Islam harus ditanamkan di Bank Pembiayaan Rakyat Syariah di Indonesia, sehingga direksi mempunyai keterlibatan kerja yang maksimum dalam melaksanakan tugas-tugas kedireksiannya.

4. Komitmen organisasi dari direksi sangat diperlukan supaya BPRS dapat berjalan dengan baik dan stabil.Untukmenghasilkan komitmen yang tinggi, direksi perlu memperhaatikan penerapan etika kerja Islam secara komprehensif.

\section{KESIMPULAN}

Penerapanetika kerja Islam merupakan suatu kaharusan bagi semua pebisnis muslim, terlebih dalam pengelolaan Bank Syariah, termasuk Bank Pembiayaan Rakyat Syariah (BPRS). Etika kerja Islam harus selalu dilaksanakan secara terus menerus dan komprehensif oleh semua Direksi dan Karyawan Bank pembiayaan Rakyat Syariah sehingga dapat menjadi ciri khusus bagi BPRS. Untuk itu komitmen menjadi tuntutan bagi seorang muslim dalam melaksanakan kerjanya.

Perubahan eksternal di berbagai bidang, akan terus berlanjut dan tidak akan berhenti.Perubahantersebut akan sangat berpengaruh pada setiap organisasi termasuk Bank Pembiayaan Rakyat Syariah (BPRS). Oleh karena itu BPRS perlu melakukan langkah-langkah untuk dapat mengelola perubahan yang terjadi salah satunya dengan meningkatkan komitmen dari seluruh elemen yang ada di dalamnya.

\section{DAFTAR PUSTAKA}

A. Sony Keraf, Etika Bisnis dan Tuntutan Relevansi (Yogyakarta: kanisius,1998).

Abdul Shukor bin Shamsudin et.al, "Preliminary Insights on the effect of Islamic work ethic on telationship marketing and customer satisfaction", The Journal of Human Resource and Adultn Learning, Vol 6, Num. 1, June 2010.

Abdurrahman Mas'ud, Menuju Paradigma Islam Humanis (Yogjakarta: Gama Media, 2003). 
Achmad Sobirin, Budaya Organisasi,Pengertian, Makna dan Aplikasinya dalam Kehidupan Organisasinya, (Jogjakarta: STIE YKPN, 2007).

Alfonsus B. Susanto, "Organizational Readiness for Change: A Case Study on Change Readiness in a Manufacturing Company in Indonesia", International Journal of Management Perspectives ISSN: 1307-1629, 2 (1), 2008.

Alma Buchori, Pengantar Bisnis, (Bandung: CV Alfabeta, 1997).

Ayu Bianda Pramadani dan Fajrianthi, "Hubungan antaraKomitmen Organisasi dengan kesiapan untuk berubah pada karyawan Divisi Enterprise Service (DES) Telkom Ketintang Surabaya", Jurnal Psikologi Industri dan Organisasi, Vol. 1 No, 12, Juli 2012.

Ayu Bianda Pramadani dan Fajrianthi, "Hubungan antara Komitmen Organisasi dengan Kesiapan untuk Berubah pada Karyawan Divisi Enterprise Service (DES) Telkom Ketintang Surabaya", Jurnal Psikologi Industri dan Organisasi, Vol. 1 No. 02, Juni 2012.

Baden, Fuller Charles, and John M Stopford, Rejuvenating The Mature Business (Harvard: Business School Press, 1996).

Bank Indonesia, Outlook Perbankan Syariah, (Jakarta: Bank Indonesia, 2013).

Bertens, K, Etika (Jakarta: PT Gramedia Pustaka Utama, 1993).

Daniel T. Holt et.al, "Readiness for Organizational Change The Systematic Development of a Scale", THE JOURNAL OF APPLIED BEHAVIORAL SCIENCE, Vol. 43 No. 2, June 2007.

Edy Setiadi, "Perbankan Syariah Harus Jadi Agenda Nasional", dalam Infobank (edisi khusus), Analisis-Strategi Perbankan \& Keuangan, (Jakarta: Infobank, 2012).

Eko B. Supriyanto, "Menerobos Jalur Lambat Keuangan Syariah", dalam Infobank (edisi khusus), Analisis-Strategi Perbankan \& Keuangan, (Jakarta: 2012).

Hengky latan, dan Imam Ghozali, Partial Least Squares Konsep, Metode dan Aplikasi menggunakan WarpPLS2.0 (Semarang: Badan Penerbit Universitas Diponegoro, 2012).

Henry Jane and david Walker, Managing Inovation, (London: SAGE Publications Ltd, 1996).

I Putu Esa Widaharthan, "Pengaruh Komitmen Terhadap Perubahan Pada Intensi Keluar", Jurnal Organisasi dan Manajemen, Vol ume 8, Nomor 1, Maret 2012.

Indira dan Ashari Bunyaanudin, "Pengaruh komitmen organisasi dan keterlibhatan kerja terhadap hubungan antara etika kerja Islam dengan sikap terhadap perubahan organisasi", JAAI, Vol 10, 2006.

Intiyas Utami dan Nur Endah Sumiwi Bonussyeani, "Pengaruh jon Insecurity, Kepuasan Kerja, dan Komitmen Organisasinal terhadap keinginan berpindah kerja", Jurnal Akuntansi dan Keuangan Indonesia, Volume 6 No. 1, 2009.

Kamahera1, "Manfaat Bagi Perusahaan Dalam Menerapkan Etika Bisnis", dalam www.wordpress.com. Diunuduh 29 Agustus 2013.

Kuat ismanto, Manajemen Syari'ah Implementasi TQM Dalam Lembaga Keuangan Syariah (Yogyakarta: pustaka belajar,2009).

Madsen Susan R et.al, " Readiness for organizational change: Do organizational commitment and social relationships in the workplace make a difference?", Human Resource Development Quarterly, Vol. 16, No. 2., 2005.

Maria Vakola and Ioannis Nikolaou, "Attitudes towards organizational Change, What is the role of employees' stress and commitment?", Employee Relations Vol. 27 No. 2, 2005.

Meglino BM, Ravlin EC dan Adkins CL, 1989, "A work value approach to corporate culture": A field testof the value congruence process and its relationship to individual outcome", Journal of applied psychologi 74, 1989.

Mochammad Maksum, "Pengaruh Etika Kerja dan Komitmen pada Organisasi terhadap Kepuasan Kerja", Majalah Ilmu dan Teknologi Pertanian, Vol. XXVI, No. 2, 2006.

Munrokhim Misanan, dkk., Ekonomi Islam, Ditulis oleh Pusat Pengkajian dan Pengembangan Ekonomi Islam (P3EI) Universitas Islam Indonesia Yogyakarta atas kerja sama dengan Bank Indonesia, (Jakarta, Rajawali Pers, 2008).

Norshidah Mohamed and Nor Shahriza Abdul Karim, "Linking Islamic Work Ethic to Computer Use Ethics, Job Satisfaction and Organisational Commitment in Malaysia", Journal of Business Systems, Governance and Ethics, Vol 5 No, 1, 2010.

O.P. Simorangkir, Etika Bisnis, Jabatan dan Perbankan (Jakarta: PT. Rineka Cipta, 2003). 
Othman Mohd. Yunus et.al, "Islamic Work Values and Organizational Commitment: A Case Study Among Employees in Broadcasting Industry", China-USA Business Review, ISSN 15371514,Vol. 11, No. 2, February 2012.

R Yudhi Satria R.A, "Hubungan antara komitmen organisasi dan iklim organisasi dengan kepuasan kerja karyawan Universitas Muhammaditah Surakata", BENEFIT, Vol 2., 2005.

Rafik Issa Beekum, Etika Bisnis Islami (Yogyakarta: Pustaka Belajar, 2004), hlm. 3.

Randall, D. M. \& Cote J. A, "Interrelationships of Work Commitment Contruct", Work and Occupation, Vol 181991.

Reichers, A.E., "Conflict and Organizational Commitment". Journal of Applied Psychology, 71, 1986.

Resi Yudhaningsih, "Peningkatan Efektivitas Kerja Melalui Komitmen, Perubahan dan Budaya Organisasi”, Ragam Jurnal Pengembangan Humaniora, Vol. 11 No. 1, April 2011.

Sabil Alrasyad, "Diskursus Etika : Problem Etika Religius Dan Etika Rasional", dalam http://sabilarasyad8.blogspot.com/2012/12/diskursus-etika.html, diakses 28 Januari 2014.

Sari Susanti Dewi dan Icuk Rangga Bawono, 2008, "Analisis pengaruh etika kerja Islam terhadap sikap karyawan bagian akuntansi dalam perubahan organisasi (studi kasus pada Bank umum Syariah di wilayah eks karesidenan Banyumas Jawa Tengah)", JAAI, Volume 12 No. 1, 2008.

Siegel,Gary \& Helene Ramanauskas Marconi, "Behavioral Accounting ", Cicinnati, Ohio: South Western Publishing Co., 1989.

Sofyan S. Harahap, Etika Bisnis dalam Perspektif Islam, (Jakarta: Penerbit Salemba Empat, 2011).

Stephen Jaros, "Meyer and Allen Model of Organizational Commitment: Measurement Issues", The Icfai Journal of Organizational Behavior, Vol. VI, No. 4, 2007.

Stephen Jaros, Meyer and, "Allen Model of Organizational Commitment: Measurement Issues", The Icfai Journal of Organizational Behavior, Vol. VI, No. 4, 2007.

Tamara, Toto, Membudayakan etos kerja Islami (Jakarta: Gema Insani press, 2002).

Tanajaya, Musa, Noegroho,S., "Perbedaan Faktor - Faktor Keterikatan Kerja Karyawan Terhadap Organisasi Ditinjau Dari Jenis Kelamin". Jurnal Psikologi Indonesia Pusat. (Jakarta : Ikatan Sarjana Psikologi Indonesia Pusat.1, 1995).

Temaluru J., Hubungan antara Komitmen terhadap Organisasi dan Faktor -faktor Demografis dengan Kepuasan Kerja Karyawan. Pengembangan Kualitas Sumber Daya Manusia dari Perspektif Psikologi Industri Organisasi, (Depok: Bagian PIO Fakultas Psikologi UI., 2001).

Teresia \& Suyasa, "Komitmen Organisasi dan Organizational Citizenship Behaviour pada Karyawan Call Center di PT. X. Phronesis". Jurnal Psikologi Industri dan Organisasi. 10 (2), 2008.

Yousef, Darwish A., "Organizational Commitment as a Mediator of the Reslationship between Islamic Work Ethic and Attitude toward Organizational Change", Human Relations Vol 53, No. 4, 2000 . 